DOI: $10.31915 / N W S .2019 .16$

\title{
Haladó funkciók és innovativ fejlesztések az EPrints és Omeka szoftverek körében
}

\author{
Nagy Dóra \\ SZTE Klebelsberg Könyvtár \\ dora.nagy@ek.szte.hu \\ Nagy Gyula \\ SZTE Klebelsberg Könyvtár \\ gyula.nagy@ek.szte.hu \\ ORCID: 0000-0002-8391-2851
}

\section{Advanced features and innovative developments of softwares including EPrints and Omeka}

The University of Szeged Klebelsberg Library has been using EPrints for handling institutional repositories since 2010. As we have progressed together with the program, we have been continually trying to exploit most of its components. In the presentation, we focus on introducing features that may be less widely used within the framework of Hungarian practice. Furthermore, some of our own innovations will also be revealed, for example, the possibilities of setting-up subject headings to the EPrints, managing file formats beyond PDF, the experience of using the statistics module, and the flexibility of designing metadata input forms.

In addition to text documents, several image collections have been recently digitized in our library. Access to these images is not provided through the institutional repositories, we use another open source software called Omeka. This system is equipped with a wide range of customizations through various extensions. It is able to manage user and access types, perform geolocations and offer various crowdsourcing techniques (collaboration, commenting, and sharing). After a brief introduction to the Omeka, some practical solutions will be demonstrated: Which types of extensions are we using? What are our future plans concerning this service? Keywords: repozitórium, képarchivum, EPrints, Omeka, tárgyszórendszer, crowdsourcing

\section{Bevezetés}

A könyvtárak mindig is élen jártak a nyilt forráskódú szoftverek használatában, így nem meglepő, hogy az elmúlt évtizedben a magyar repozitóriumi hálózat is ilyen alapokon épült ki. Tanulmányunk első felében ennek a hálózatnak az egyik alapvető épitőkövét jelentő szabad szoftver, az EPrints repozitóriumkezelő rendszer kevésbé ismert, haladó lehetőségeit-funkcióit szeretnénk bemutatni (1.1.-1.6. fejezet). A második részben pedig egy a hazai gyakorlatban még kevésbé elterjedt, elsösorban képek és más médiaállományok kezelésére kifejlesztett ingyenes, Omeka nevü szoftver néhány bővitményének bemutatása olvasható (2.1.-2.2. fejezet). A programok általános szintủ ismertetésén túl elsősorban azokra a magasabb szintü müveleteket megvalósitó kiterjesztett szolgáltatásokra koncentrálunk irásunkban, amelyek használata még kevésbé gyökeresedett meg a hazai gyakorlatban. Erre próbálunk utalni irásunk címében a "haladó funkciók" szófordulattal. Azokat a 
plusz szolgáltatást nyújtó lehetőségeket nevezzük haladó funkcióknak, amelyek nem érhetőek el a szoftver alap telepitésekor, vagy esetleg valamilyen rejtett funkcióként jelennek csak meg. A bemutatott esetekben ezen funkciók teljes körü kihasználásához bővitmények telepitése, konfigurálása, esetleg önálló fejlesztések adaptálása is szükséges.

\subsection{EPrints - Statisztika bövítmény}

Ezek körébe tartozik az EPrints statisztika bővitménye, amely 35 hazai EPrints repozitóriumot tekintve csak 14 esetében van telepítve, melyböl 12 SZTE megvalósitású. Saját EPrints repozitóriumainkon kivül a BGE Publikációtárnál és Dolgozattárnál, valamint a Corvinus Disszertációk és Kutatások repozitóriumoknál érhető el ez a modul.

Maga az IRStats2 nevü statisztika bővitmény az EPrints Bazaar bövitménykezelö felületéröl telepithető. Rengeteg féle statisztikai adatot kinyerhetünk segítségével. Többek között kilistázza a legtöbbször letöltött szerzöket és müveket, a repozitóriumban lévő tételek számát, az összes letöltésszámot, illetve a bővitmény telepitésétöl kezdve grafikonon is ábrázolja a letöltési adatokat, piros vonallal megjelenitve az összesitett átlagot. A bővitmény segítségével különféle jelentések elkészitése, illetve a tételek többféle szempont szerinti szürése is lehetséges. Kimutatható például a letöltések országonkénti forrása (térképen ábrázolva), évenkénti összehasonlítás végezhető a repozitórium gyarapodásáról, illetve a dokumentumok tipus szerint is megjelenithetőek grafikonon. Az eredmények XML, JSON és CSV formátumban exportálhatók. Az SZTE Publicatio Repozitóriumnál az egyes tételek összefoglaló oldalán szintén megjelenik az adott rekordhoz tartozó letöltési statisztika.

Az összes SZTE-s repozitórium nyitóoldalán elérhető a statisztika föoldalára mutató link, amely szabadon böngészhetö. Felhasználóink pozitiv visszajelzései alapján helyes döntésnek bizonyult a statisztikai adatok nyilvánossá tétele, hiszen így pontos képet kaphatnak a repozitóriumban lévő anyagok használtságáról, ami tovább növelheti a népszerüséget és az érdekeltséget.

\subsection{EPrints - Kötegelt szerkesztési lehetőségek adminisztrátori felületen}

Munkánk során rendszeresen használjuk az adminisztrátori felületen elérhetö kötegelt szerkesztési lehetőséget. Több száz rekord betöltésekor a Batch Editing Tool segitségével történik az élö archívumba mozgatás, emellett hatékonyan használható különféle metaadatok tömeges javítására. Ilyenkor az adminisztrátori felületen a 'Tételek keresése' menüben lekeressük a módositani kivánt rekordokat, majd a találati lista bal felsö sarkában a 'Batch Edit' lehetöségre kattintva jutunk arra a felületre, ahol a legördülö menüből kiválasztható az az EPrints mező, amelyet korrigálni szeretnénk, majd a 'Hozzáadás' gombra kattintva írhatjuk be az új értéket. Öt féle müvelet hajtható végre, ami a mező típusától függően eltérő. Lehet törölni a mező teljes tartalmát vagy a tartalom egy részét, hozzáirni új adatot a meglévők elé vagy mögé, illetve karaktersorozatot cserélni. 


\section{Statisztika}

\section{Összes tétel}

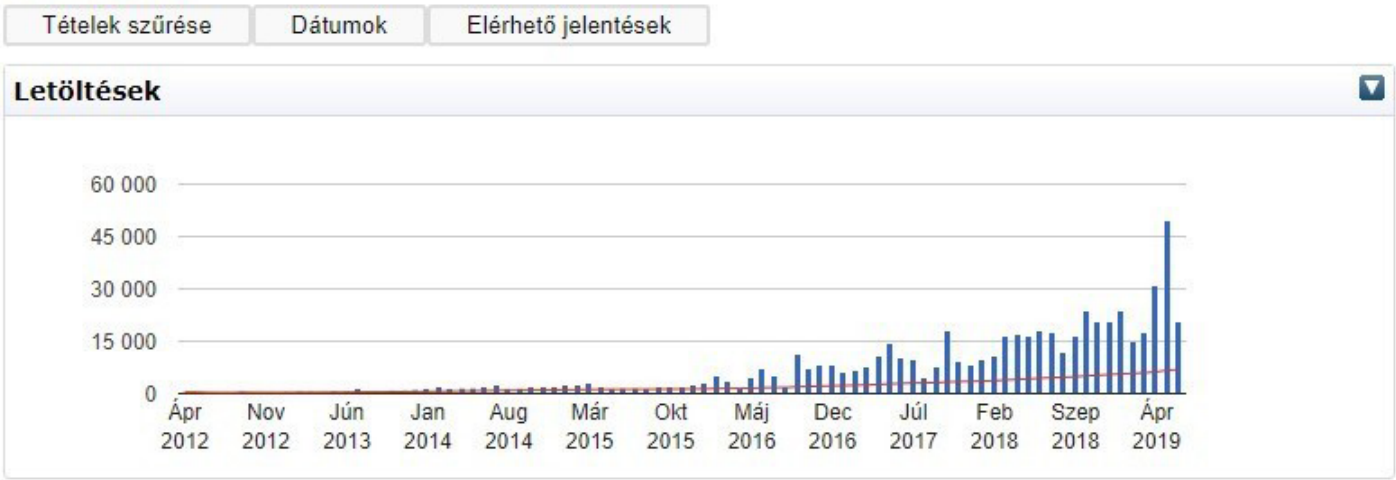

\section{Tevékenységek áttekintése}

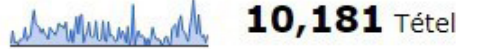

$\mathbf{1 0 0} \%$ Teljes szöveg
65\% Nyilt hozzáférés

\section{Legtöbbször letöltött tételek}

1. Melyiket válasszuk? - Tények és

1. érvek a diklofenák sókról

2. What is Privacy? The History and

2. Definition of Privacy.

3. Az európai integráció politikai története

\section{\begin{tabular}{l|l}
$\mathbf{5 9 6}, 045$ Letöltések \\
\hline
\end{tabular}}

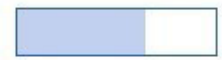

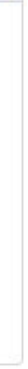




\subsection{EPrints - Összetett ürlap több szereplö kiszolgálására}

Az EPrints képes arra, hogy olyan beviteli ürlapot definiáljunk, amelynél az egyes mezőkhöz és állomásokhoz csak bizonyos jogosultsággal rendelkezők férhetnek hozzá. Az SZTE Publicatio Repozitóriumnál és az SZTE Elektronikus Tananyag Archivumnál beépitettük ezt a lehetőséget, ugyanis ezek esetében külső felhasználók is töltenek fel anyagokat: elöfordulnak olyan adatmezök, melyek csak a szerkesztők számára relevánsak, ezekkel nem akartuk feleslegesen terhelni a feltöltöket, emiatt számukra egy egyszerüsitett ürlap jelenik csak meg a legfontosabb mezőkkel.

Emellett, a munkafolyamat konfigurációja során lehetöség van különböző elágazások létrehozására is. Nem csak felhasználó, hanem EPrints típus szerint is változtatni lehet a különböző metaadatmezöböl álló ürlapokat: például videók esetében releváns a 'Lejátszási idő', míg könyv típusnál az 'ISBN'. A fent emlitett két repozitórium esetében a jogi nyilatkozatot is hasonló elágazással oldottuk meg. Ez a legelső állomás, melyre a felhasználó érkezik, ha új rekordot szeretne létrehozni, és csak akkor tud továbblépni, ha elfogadta a nyilatkozatot.

\subsection{EPrints - edulD}

Az SZTE Open Online Oktatás (SZTE O3) stratégia és az EFOP-3.4.3-16-2016-00014 projekt megvalósitásának részeként az SZTE Elektronikus Tananyag Archivum feladata az egyetemen keletkezett tananyagok hosszú távú megörzésének biztositása, szakszerü feldolgozása és szolgáltatása. A tananyagok megfelelő elérésének biztositására szükségessé vált egy új, eddigi repozitóriumainknál még nem használt hozzáférési típus bevezetése. Az edulD használatára több hazai adatbázisnál láthatunk példát (Szaktárs, Typotex), amely megoldás kivitelezhető intézményi repozitóriumoknál is. Jelenleg csak saját IDP-hez (Identify Data Provider) van bekötve az autentikáció, igy egyelöre csak SZTE-s eduID-vel müködik a rendszer.

\subsection{EPrints - PDF-en túli fájlformátumok}

A repozitóriumokban általában PDF formátumban tároljuk, szolgáltatjuk a digitalizált vagy eleve elektronikusan keletkezett anyagokat, azonban az EPrints valójában sokféle fájlformátumot képes kezelni: MP3, ZIP, PPT stb. Ha az adott fájlformátumot a böngésző támogatja, akkor külső program igénybevétele nélkül, a böngészöben is megtekinthetőek a tartalmak. Ilyen formátumok a PDF, a HTML, a különböző kép és videó fájlok (JPG, MP4 stb.).

Az SZTE Elektronikus Tananyag Archívumban elkezdtünk HTML oldalakat is archiválni, ugyanis rengeteg ilyen típusú tananyagot találtunk, melyeket nem lehetett PDF formátumba konvertálni az interaktív megoldásaik miatt.

HTML oldalak archiválása a következöként történik: a lementett oldalt egy tömöritett mappában feltöltjük EPrints-be, majd rendszeren belül kicsomagoljuk 'Single' módban, ezután lehet kiválasztani a fö fájlt (ami általában index.html). Nyilvános felületen a rekordban csak a fő fájl jelenik meg, a többi háttérben marad. Ezzel a megoldással felhasználóbarát módon lehet böngészni a weboldalt EPrints-en belül, nem kell a csomagot saját gépre letölteni. 
Tétel nézet: Fizikai optika

Ez a tétel URL címmel van az Repozitóriumban:

http://eta.bibl.u-szeged.hu/1693/

Tétel visszavonása Mozgatás vissza a Feladatok kōzé

Tétel megsemmisitése

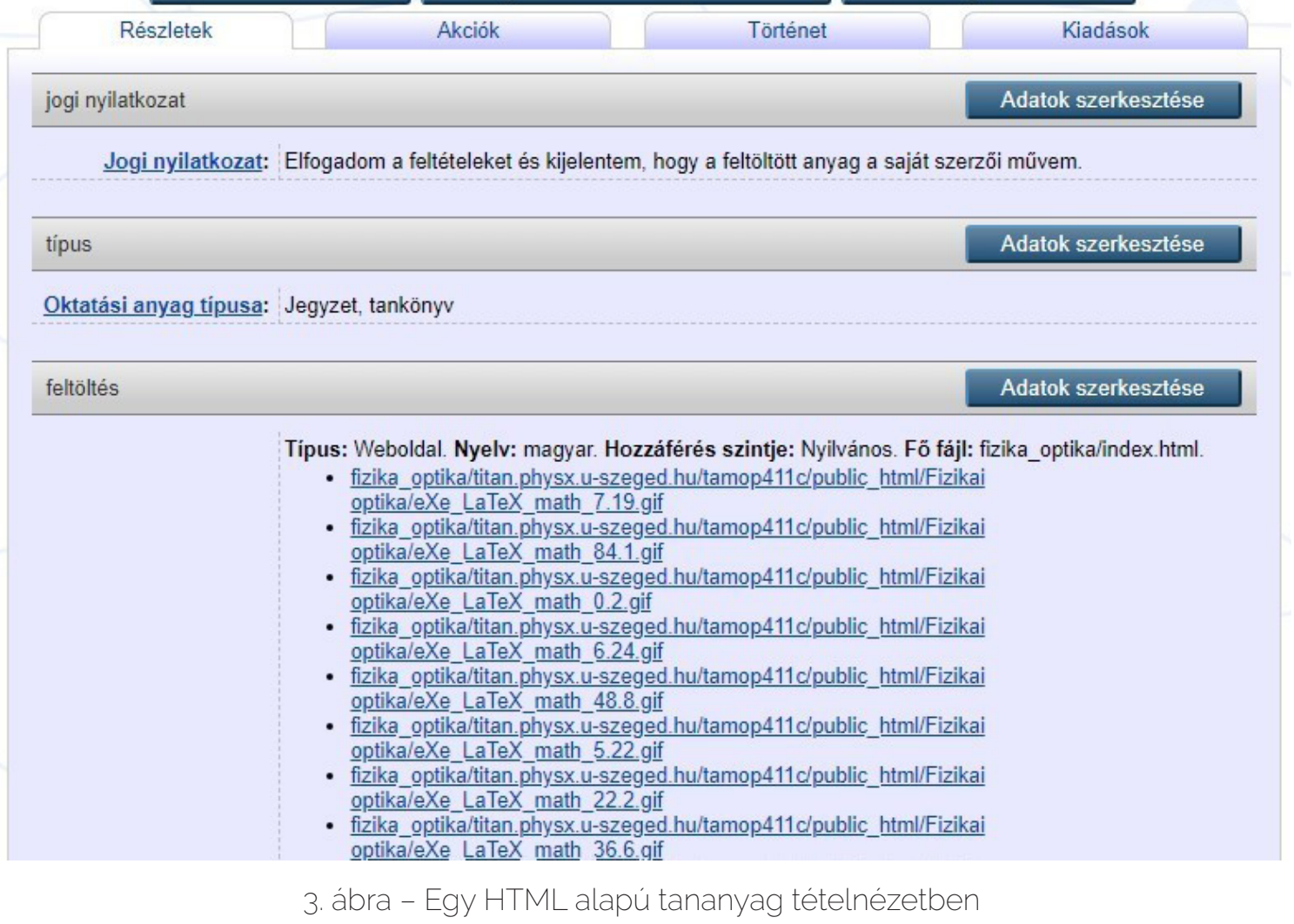

\subsection{EPrints - Szakterületi besorolás}

Mivel a tananyagok az egyetem minden karáról érkezhetnek, a tartalmi feltárást elösegitendő bevezettünk egy szakterületi besorolást. Ehhez a H2O2O projekthez készitetthétszintes, angolés magyar ${ }^{1}$ nyelven is rendelkezésreállótárgyszórendszert választottuk, melyet a megújult MTMT2 is beépitett. A taxonómia két ágra bomlik: "Tudomány" ( $N=\sim 3400) ;$ "Gazdálkodás és innováció" ( $N=\sim 300)$. Az EPrints illesztés során a témák mindegyike új ID-t kapott, illetve kivettük belőle a 'Gazdálkodás és innováció' ág kategóriáit. A táblázatot az elkészitett XML séma alapján EPrints-be

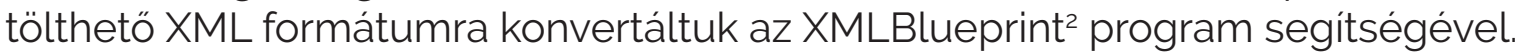

Az EPrints-en belül a 'subject' típusú mezö tartalmazza a tárgyszavakat, melyek módositására, kiegészitésére az adminisztrátori felületen van lehetöség. A rekord szerkesztési munkafolyamatában egy külön lapon kaptak helyet a szakterületek, melyek közül több is hozzárendelhetö egy rekordhoz. A külsö, nyilvános felületen a böngészés szakterület szerinti nézetben csak azok a kategóriák láthatóak, melyekhez van már rekord rendelve. Ezek tovább csoportosithatók szerző és oktatási anyag típusa szerint, valamint minden besorolt rekord tételnézetében is megjelennek a tárgyszavak.

\footnotetext{
$1 \quad$ A forditás Tichy-Rács Ádám munkája.

2 XML Editor - XMLBlueprint. https://www.Xmlblueprint.com
} 
(c) (i)

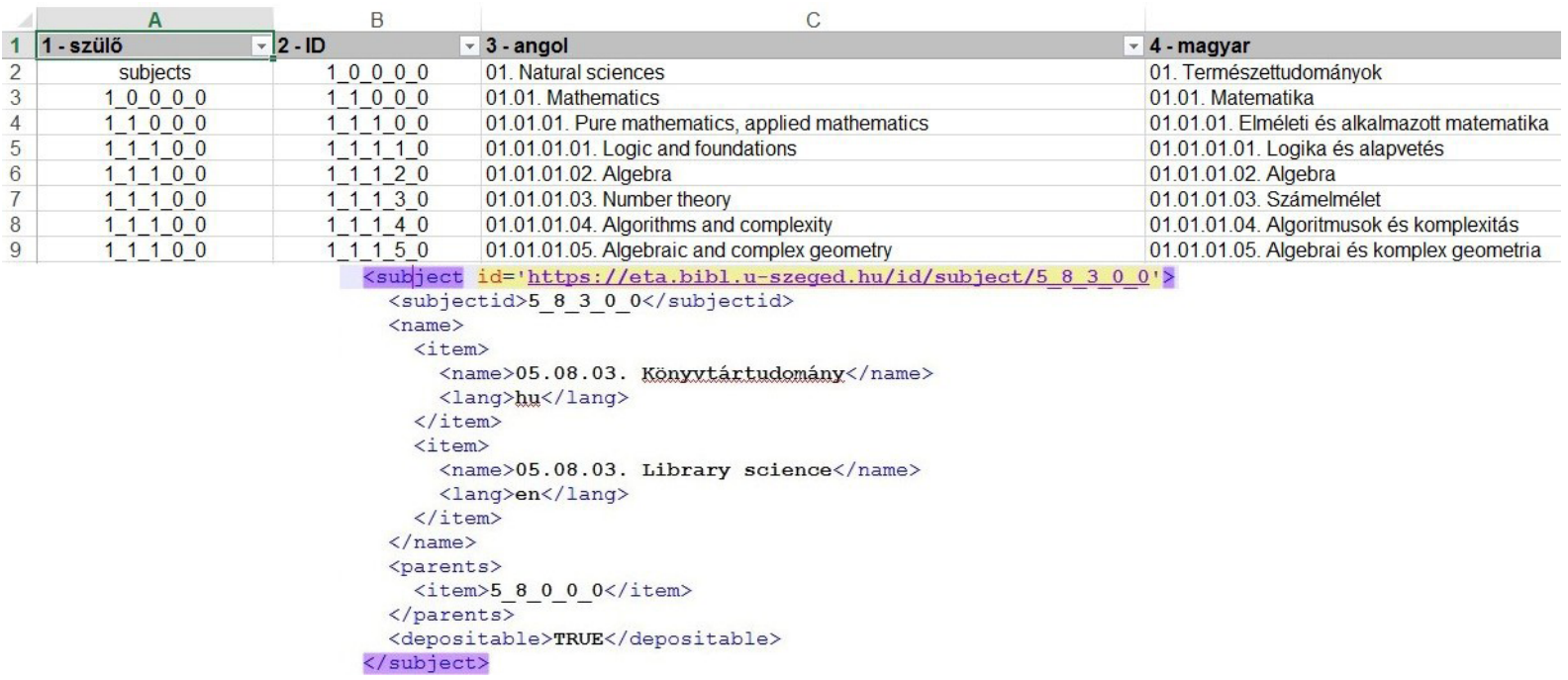

4. ábra - Az átalakitott táblázat, valamint a betöltésre kész XML részlete

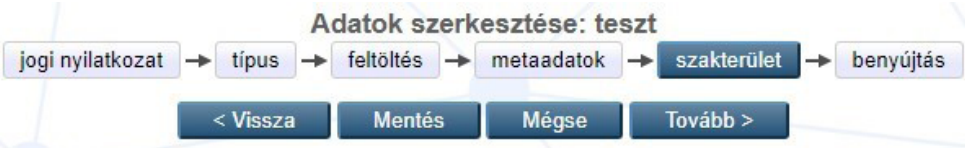

\section{Szakterület}

Válassza ki a listából azt a kategóriát, amely a legmegfelelöbb. Ha szükségesnek látja, további két-három kategóriát is megjelölhet. A 'Hozzáadás' gombot használva lehet kinyitni az alsóbb kategóriákat.

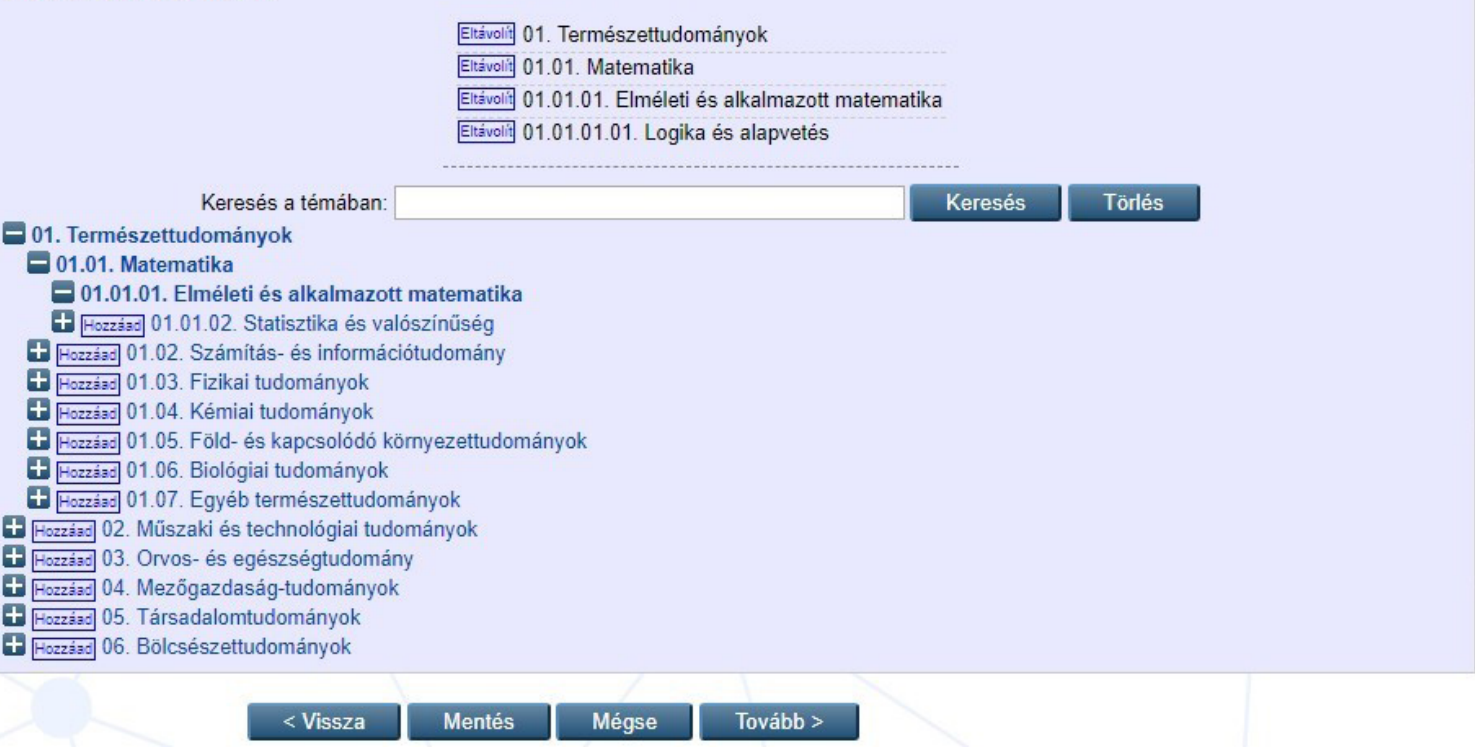

5. ábra - Szakterületek az EPrints szerkesztői felületén

Ezt a szakterületi besorolást jelenleg az SZTE Elektronikus Tananyag Archívumban használjuk, detervezzükbevezetniazSZTEPublicatioésazSZTEDoktorirepozitóriumokban is. 


\subsection{Omeka - Általános tulajdonságok}

Nemrégiben új intézményi kép- és médiaarchivum ${ }^{3}$ kialakitása vált szükségessé a korábbi MARC alapú képi nyilvántartásaink kiváltására. Erre a célra az Omeka Classic szoftvert választottuk, mely egy könyvtárak, múzeumok, levéltárak számára létrehozott nyiltt forráskódú program, amit 2007-töl fejleszt a Roy Rosenzweig Center for History and New Media intézet. A projekt támogatói között szerepel többek között a Library of Congress is ${ }^{4}$

A müködéshez szükséges környezet: Linux operációs rendszer; Apache HTTP szerver; MySQL adatbázis-kezelő; PHP szkriptnyelv és ImageMagick képszerkesztő ${ }^{5}$ Kezelöfelülete hasonlít az elterjedt tartalomkezelő rendszerekhez, mint pl. a WordPress, így viszonylag könnyen megtanulható a kezelése.

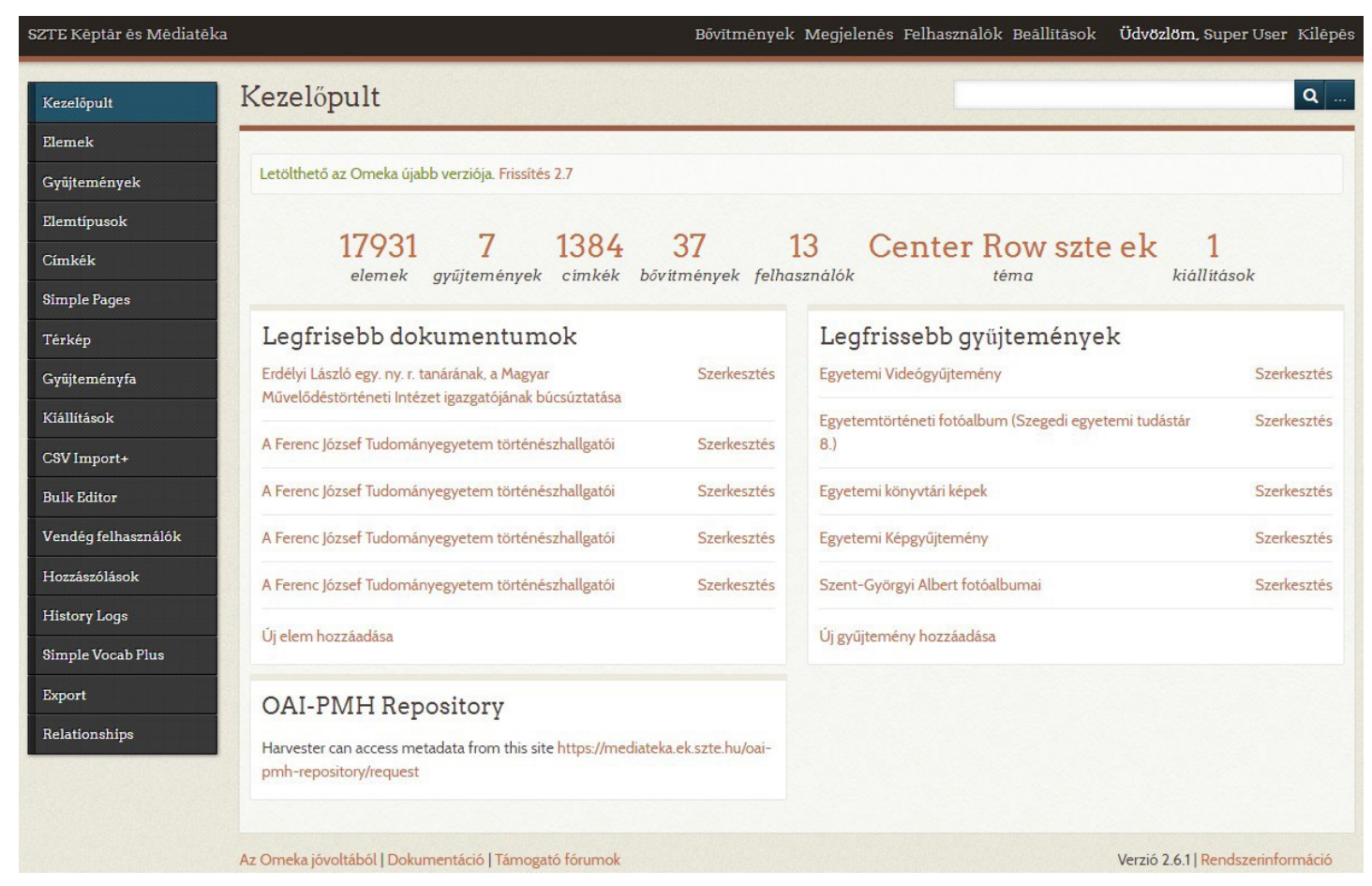

6. ábra - Az Omeka Classic adminisztrátori felülete

Az Omekát részben a részletes dokumentáció miatt választottuk, nem csak felhasználói ${ }^{6}$, de fejlesztői szempontból is jól dokumentált, valamint aktiv felhasználói közösség virágzik a hivatalos fórumon ${ }^{8}$. A közösségi segitséggel készült forditásokat a Transifex szolgáltatáson keresztül9 gyüjtik. Kollégáink segitségével

\footnotetext{
3 SZTE Képtár és Médiatéka. https://mediateka.ek.szte.hu

Az Omeka projektröl. https://omeka.org/about/project

Omeka Classic rendszerkövetelmények. https://omeka.org/classic/docs/Installation/ System_Requirements

Omeka Classic felhasználói dokumentáció. https://omeka.org/classic/docs

Omeka Classic fejlesztői útmutató. https://omeka.readthedocs.io/en/latest

Omeka Classic fórum. https://forum.omeka.org/c/omeka-classic

Omeka Classic fordítások. https://www.transifex.com/omeka/omeka
} 
elkészitettük több bövitmény és az alaprendszer nagy részének magyar fordítását, amely elérhető a fent említett oldalon és bekerült az Omeka Classic legújabb 2.7es verziójába.

A sokrétü tartalomszolgáltatási funkcióknak köszönhetöen a szolgáltató intézmények igényeihez jól igazitható a rendszer. Használhatjuk a már elérhető témák egyikét ${ }^{10}$, de elkészithetjük saját, intézményi arculathoz igazodó megjelenésünket is. A különféle bővitmények segitségével térképen ábrázolhatjuk a rekordjainkat és virtuális kiállitásokat készithetünk belölük. Felhasználóinkat is bevonhatjuk a feldolgozás folyamatába, hozzászólások és egyéb közremüködések formájában. Mivel a rendszer képes többféle felhasználótípus kezelésére, alkalmas crowdsourcing projektek megvalósitására is.

A feltöltési folyamat többlépcsős, illetve egy elemhez több fájl is feltölthető. Első lépés a metaadatmezők kitöltése, majd az elem típusának meghatározása (kép, hanganyag, szöveg stb.). Ezután lehet feltölteni a fájlokat, címkéket hozzáadni és egyéb bővitmények nyújtotta lehetöségeket használni pl. térképen megjelölni a helyszint.

Egy elem lehet nyilvános vagy privát. Utóbbi nem jelenti feltétlenül azt, hogy a felhasználóktól teljesen elzárt lenne. Az Omeka Classicban alapból elérhető négy felhasználótipus egyike a 'Researcher' felhasználó, aki megtekintheti a nyilvános és zárt tartalmakat is, de semmilyen módon nem tudja azokat módositani. Vagyis megengedjük a felhasználóinknak, hogy regisztráljanak az oldalunkra, ahol adminisztrátori jóváhagyás után a kutatók hozzáférést kaphatnak a teljes gyüjteményhez. A további felhasználótipusok a következők: 'Super' (legmagasabb szintü jogosultság), 'Admin' (új elem feltöltése ès a már meglévő elemek szerkesztése, törlése), 'Contributor' (új elem feltöltése, ami csak ellenörzés után nyilvános). A Guest User bővitmény segitségével megadható egy ötödik típus, az úgynevezett 'Guest' felhasználó, amely szükséges más bővítmények müködéséhez (pl. Commenting).

Mivel az Omeka Dublin Core metaadat-struktúrát használ, a meglévő MARC rekordjainkat át kellett alakítani. Ehhez az ingyenes MarcEdit programot használtuk, amivel először egy CSV fájlba konvertáltuk az adatokat, majd a MARC mezőneveket helyettesitettük a megfelelö Dublin Core adatelemre és az így elkészült metaadatokat és fájl elérési utat is tartalmazó CSV fájlt betöltöttük Omekába a CSV Import+ bővitmény segitségével ${ }^{11}$.

Bekerült az a jelentős képanyag is, melyek digitalizálása megtörtént az évek során, de még nem lettek egy rendszerben sem feldolgozva, így négy fö gyüjteményt alakitottunk ki: Egyetemi Arcképcsarnok; Egyetemi Képgyüjtemény; Shvoy Kálmán fotóalbumai; Szent-Györgyi Albert fotóalbumai (utóbbi három származik

10 Omeka Classic témák. https://omeka.org/classic/themes.

11 Részletek: Nagy Gyula, Nagy Dóra, Sándor Ákos: Tömeges adatkonverzió és rugalmas export-import lehetőségek az EPrints, OJS és Omeka szoftverek körében 

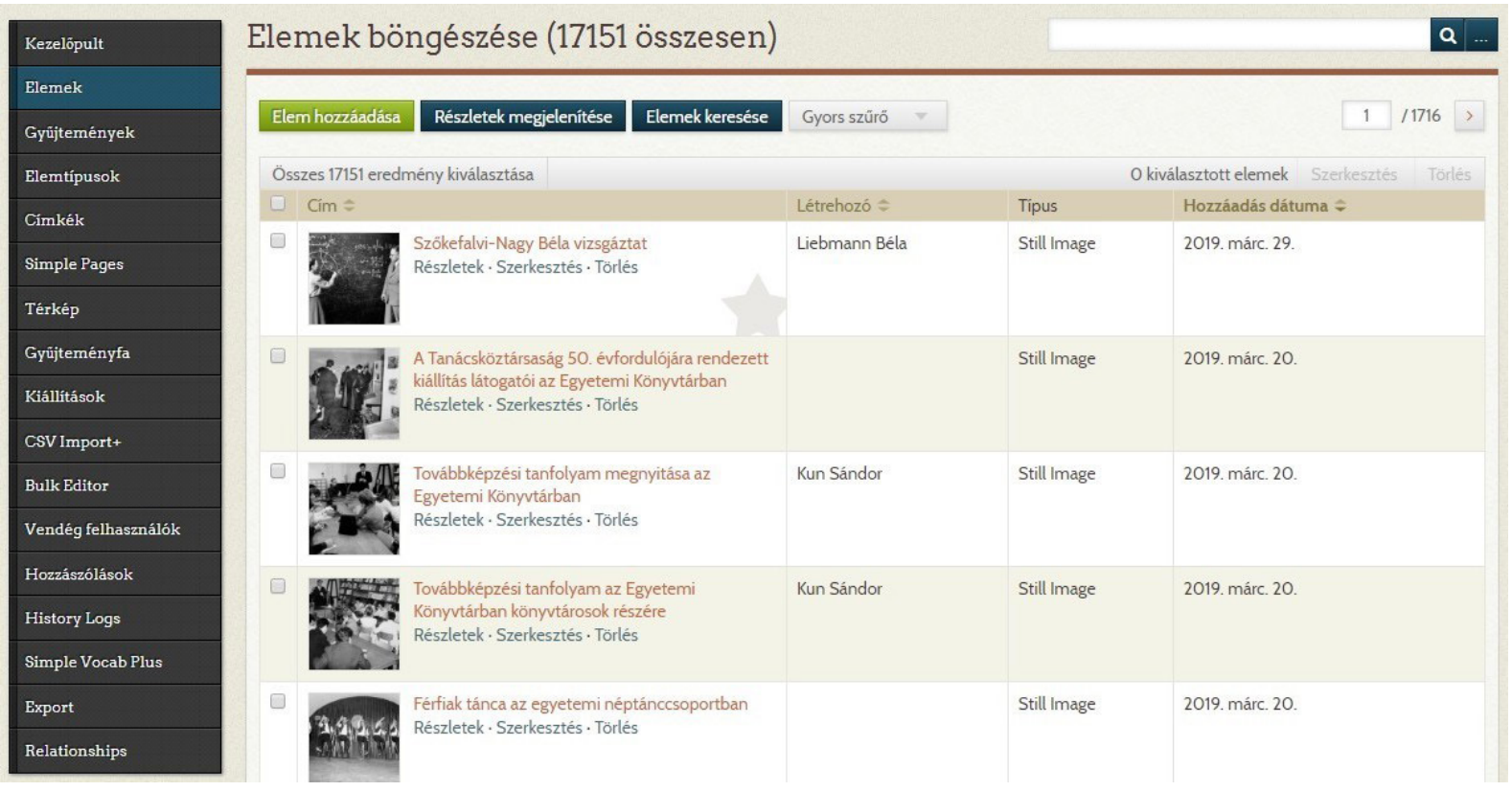

7. ábra - A betöltött elemek az adminisztrátori felületen

MARC adatbázisból). Utóbb létrehoztunk két algyüjteményt is az Egyetemi Képgyüjteményen belül: Egyetemi könyvtári képek és Egyetemtörténeti fotóalbum. A videófelvételek az Egyetemi videógyüjteményben találhatóak meg. Jelenleg is több, mint 16000 nyilvános és 1500 feldolgozásra váró elemet tartalmaz az adatbázis. A további gyarapodása folyamatos, az újonnan bekerülő és a meglévő papíralapú képanyag digitalizálása révén.

\subsection{Omeka - Bövítmények}

A hivatalos oldalon több, mint 90 bővítmény ${ }^{12}$ található, melyböl mi 21-et használunk, ezek közül sorolunk fel néhányat:

- A Dublin Core Extended bővitmény hozzáadja az összes Dublin Core metaadat mezőt a már meglévő alap 15 adatelemhez (pl. létrehozás dátuma).

- Az OpenStreetMap alapú Geolocation bővítmény használható az egyes elemek térképen való ábrázolására.

- A CSV Import+ bövitmény nemcsak metaadatokat és fájlokat, hanem egyéb adatelemeket pl. geokódokat is tud importálni. Többféle CSV struktúra áll rendelkezésre, melyek segitségével egy rekordhoz több fájl is betölthető egyszerre; utólagos nagy tömegü módosítás is végrehajtható, illetve az egész betöltés vissza is vonható.

- Az Exhibit Builder bövítménnyel lehet több aloldalt is tartalmazó virtuális kiállítást létrehozni, melynek akár a föoldaltól eltérö egyedi témát is készithetünk. Az Exhibit Image Annotation ezen belül a képen szereplö dolgok megjelölésére (tagelésére) alkalmas. 
- A Commenting bővitmény hozzászólási lehetőséget biztosít a felhasználóknak. A Guest User bővitménnyel együttmüködve egy olyan felhasználói típust hoz létre, amely csak hozzászólás irására képes, bejelentkezés és adminisztrátori jóváhagyás után. A Social Bookmarking bővitmény minden elemhez megosztás gombokat társit (pl. Facebook, Twitter). Mig a SimpleContactForm regisztráció nélküli üzenetküldésre használható.

Ezek mellett több bővitmény tesztelése zajlik, ilyen például az AvantRelationship, mellyel kapcsolati háló hozható létre az egyes elemek között. A Simple Vocab Plus bővitménnyel pedig ajánló tárgyszólista készithető. A tartalmi bővülést tekintve folyamatos a Szent-Györgyi Gyüjtemény feldolgozása, illetve további hagyatéki és egyetemi vonatkozású kép- és videóanyagok betöltése és feldolgozása. 